\title{
Investigating Knowledge as a Possible Predictor of Purchase Intention among Muslims in Malaysia for Life Insurance and Takaful
}

Nurul Farhana Nasir, Rosmimah Mohd Roslin, Muhammad Nur Firdaus Nasir, Muhammad Faiz Nasir, Muhammad Arif Nasir, Nor Aizan Mohamed

To Link this Article: http://dx.doi.org/10.6007/IJARBSS/v11-i2/8880 DOI:10.6007/IJARBSS/v11-i2/8880

Received: 10 January 2021, Revised: 02 February 2021, Accepted: 14 February 2021

Published Online: 27 February 2021

In-Text Citation: (Nasir et al., 2021)

To Cite this Article: Nasir, N. F., Roslin, R. M., Nasir, M. N. F., Nasir, M. F., Nasir, M. A., \& Mohamed, N. A. (2021). Investigating Knowledge as a Possible Predictor of Purchase Intention among Muslims in Malaysia for Life Insurance and Takaful. International Journal of Academic Research in Business and Social Sciences, 11(2), 727-740.

Copyright: (c) 2021 The Author(s)

Published by Human Resource Management Academic Research Society (www.hrmars.com) This article is published under the Creative Commons Attribution (CC BY 4.0) license. Anyone may reproduce, distribute, translate and create derivative works of this article (for both commercial and non-commercial purposes), subject to full attribution to the original publication and authors. The full terms of this license may be seen at: http://creativecommons.org/licences/by/4.0/legalcode

Vol. 11, No. 2, 2021, Pg. 727 - 740

Full Terms \& Conditions of access and use can be found at http://hrmars.com/index.php/pages/detail/publication-ethics 


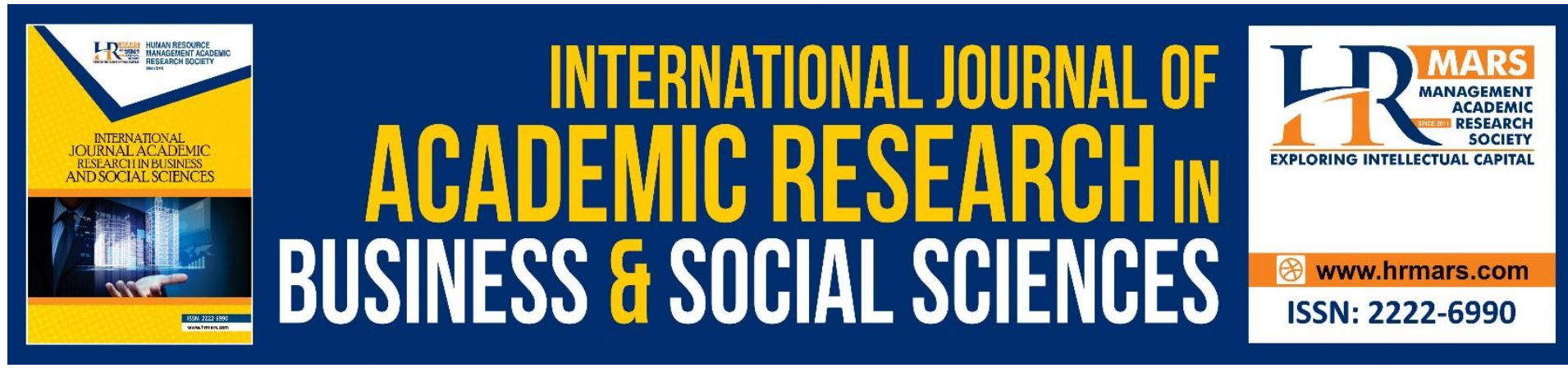

\title{
Investigating Knowledge as a Possible Predictor of Purchase Intention among Muslims in Malaysia for Life Insurance and Takaful
}

Nurul Farhana Nasira, Rosmimah Mohd Roslin ${ }^{\mathrm{b}}$, Muhammad Nur Firdaus Nasirc , Muhammad Faiz Nasir ${ }^{\mathrm{d}}$, Muhammad Arif Nasire , Nor Aizan Mohamed ${ }^{f}$

${ }^{a}$ Faculty of Business Management, Universiti Teknologi MARA Melaka, Malaysia, ${ }^{b}$ Arshad Ayub Graduate Business School, Universiti Teknologi MARA Shah Alam, Malaysia, 'Faculty of

Art and Design, Universiti Teknologi MARA Melaka, Malaysia, ${ }^{\mathrm{d}}$ Faculty of Business Management, Universiti Teknologi MARA Shah Alam, Malaysia, e Faculty of Hospitality and

Tourism, Kolej Universiti Islam Melaka, Malaysia, ${ }^{f}$ Faculty of Business Management, Universiti Teknologi MARA Kampus Bandaraya Melaka, Malaysia

\begin{abstract}
This study investigates the purchase intention of Muslim consumers in Malaysia towards life insurance and Takaful. It focuses on the relationships between attitude, social norms, perceived behavioural control and knowledge on purchase intention. The Theory of Planned Behaviour is utilized as the basis of the framework to examine the key determinants that would encourage Muslims to purchase life insurance and Takaful. Data was analyzed using Partial Least Squares. A total of 316 questionnaires was obtained from a distribution of 580 questionnaires in the Klang Valley. The study found that attitude, social norms, and perceived behavioural control are predictors of intention to purchase life insurance and Takaful. However, knowledge was not a significant predictor influencing Muslims to purchase life insurance and Takaful. The findings downplay the role of knowledge of unsought goods like life insurance and Takaful on the purchase intention among Muslims.
\end{abstract}

Keywords: Life Insurance, Takaful, Theory of Planned Behavior, Purchase Intention

\section{Introduction}

In the world that we live in today, the possibilities of perils are ever present. Perils that are associated with destruction, injury or death often lead to losses that are at times unanticipated. As such, the association of perils and risks is common as risk relates to the possibility of unexpected adversities that might happen in the future (Olsson, 2002). It is often difficult to predict the likelihood of perils and the underlying risks as risks may be present everywhere and in any circumstances. Even though we are uncertain about future losses, as Muslims, one should take the effort to minimize the outcome of the loss.

One of the effective ways to minimize losses is by transferring the risks to a third party or to the life insurance service provider. Life insurance is the contractual agreement between 
the insured (i.e. people who are covered) and the insurer (i.e. insurance company) according to a stipulated agreement in the contract. According to Rejda (2004), life insurance is an important mechanism to handle risks. Although, there are a lot of life insurance and Takaful products in the market, there are still very limited Muslims purchasing life insurance and Takaful. The reasons behind such resistance require an in-depth understanding and life insurance and Takaful operators should initiate and find means of stimulating demands to enhance the market growth of life insurance and Takaful. There is therefore a need to understand key factors that are needed to encourage Muslims to purchase life insurance and Takaful. Thus, this paper addresses the gaps that exist empirically in the Theory of Planned Behaviour (TPB) to further investigate other possible factors that might encourage Muslims to purchase life insurance and Takaful.

The TPB constructs comprising of attitude, subjective norm, and perceived behavioural control on intention to purchase have been validated in previous studies in different contextual settings (Gu \& Wu, 2019; Putra \& Nurdin, 2018; Zhang, Chen, Wu, Zhang, \& Song, 2018; Alam \& Sayuti, 2011). The utilization of TPB as the theoretical framework in this study is deemed relevant as life insurance and Takaful may pose different purchase possibilities due to the contextual implications. Previous studies have proposed knowledge as a possible predictor to be included as the determinant in influencing the intention to purchase (Husin \& Rahman, 2013) and in the setting of life insurance and Takaful, knowledge may well be a much needed stimulus. As such, this study is conducted to include knowledge as a new determinant to predict the intention to purchase life insurance and Takaful among Malaysian consumers.

\section{Literature Review}

The Theory of Planned Behavior (TPB) was developed by Ajzen (1991) to overcome the limitation of the Theory of Reasoned Action (TRA) that was previously developed by Ajzen and Fishbein's (1980). TRA explained the volitional characteristics present in attitude and subjective norm toward behaviour. Prior studies by Ajzen and Madden (1986) later found the weaknesses of TRA in relation to predictors that are essentially non volitional. Hence, perceived behavioural control construct was introduced to overcome the limitation of TRA. Basically, TPB links attitude, subjective norm, and perceived behavioural control with behavioural intention.

Attitude is the evaluation of positive or negative perception of the individuals towards behaviour (Fishbein \& Ajzen, 1975). Potential buyers of life insurance and Takaful are perceived to have positive attitude towards life insurance and Takaful because it is a risk mechanism used to minimize possible losses in the future. Past researches have documented the significant effect of attitude towards intention (Kasuma et al., 2020; Jalilian et al., 2020; Hasan \& Suciarto, 2020; Rahadjeng \& Fiandari, 2020; Yajid, Shukri, \& Azam, 2020).

Social pressure influencing intention to purchase life insurance and Takaful is known as subjective norm. Subjective norms or also known as social norms is the second determinant identified in TPB. Subjective norms is the pressure from the surrounding including that of people, whether to perform or not the behaviour (Ajzen, 1991; Ajzen \& Fishbein, 1980). Basically, such social pressure comes from various sources including that of peers, spouse, officemates or family. It is possible for people to perform the behaviour if they are pressured by those in their surroundings. The significant effects of subjective norms (i.e. social norms) on intention have been validated in past studies (Arpaci, 2020; Keat, Zakaria, \& Mohdali, 2020; Anastasia \& Santoso, 2020; Gultom et al., 2020; Usman \& Novianawati, 2020; Khairi, Laili, \& Kamarubahrin, 2020). 
Perceived Behavioural Control is the third determinant in TPB. Ajzen (1991) explained perceived behavioural control as the controllable actions by people in performing the behaviour. Although a person may have positive attitude and have the encouragement from the surrounding, the intention to purchase is lower if he/she is not equipped with sufficient resources (Madden \& Ajzen, 1992). Essentially there are prior researches that have validated the significant effect of perceived behavioural control on intention (Jalali et al., 2020; Utami, 2017; Nasir, Roslin, \& Chui, 2020; Nursalwani \& Zulariff, 2017; Nikita, 2015).

As much as the determinants established in TPB have been well documented, there are studies that revealed that TPB is insufficient to fully explain individuals' behavioural intentions. Hence, the researchers have included the element of knowledge to enhance the predictive power of the proposed model. The justification for adding this construct is based on Ajzen's (2020) review of TPB on the possibility of adding a new predictor that is behaviourspecific, has causal implications, and applicable to a wide range of behaviour. In many varying contexts, past researches have validated the significant effect of knowledge on intention (Fabiola \& Mayangsari, 2020; Sulaiman, Kan, \& Salimon, 2020; Khairunnisa \& Hendratmi, 2019; Husin \& Rahman, 2016). It is postulated in this study that by having knowledge, potential buyers of life insurance and Takaful are more willing to purchase life insurance and Takaful as they are likely to have more in-depth understanding of the products. Knowledge is regarded as the process gained through knowing or having learned or experienced (Agarwal, 2017). Hence, the inclusion of knowledge in the framework appears to be relevant in this study.

\section{Conceptual Framework}

This study develops a framework based on the TPB, with determinants consisting of attitude, social norms, and perceived behavioural control, and also extends TPB by incorporating a relevant construct that is knowledge. This study proposes that attitude, social norms, perceived behavioural control, and knowledge will positively influence purchase intention. The conceptual framework for this study is shown in Figure 1.

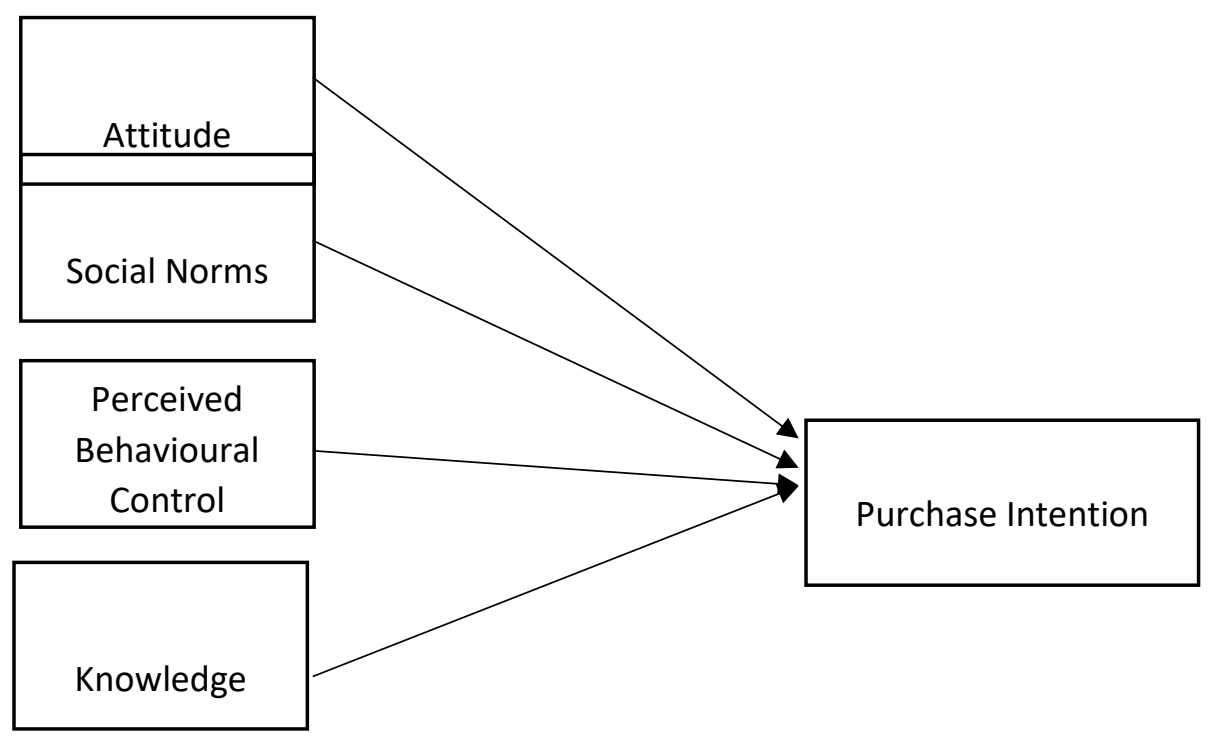

Figure 1: Framework 
Thus, four hypotheses are formulated based on the above framework:

$\mathrm{H} 2$ : Attitude will positively influence the purchase intention of life insurance and Takaful

$\mathrm{H} 2$ : Social norms significantly influence purchase intention of life insurance and Takaful

$\mathrm{H} 2$ : Perceived behavioural control positively influence purchase intention of life insurance and Takaful

$\mathrm{H} 2$ : Knowledge significantly influence purchase intention of life insurance and Takaful

\section{Methodology}

The sample of this study were potential buyers of life insurance and Takaful in the Klang Valley, Malaysia. The respondents of the study were Muslims who do not presently have life insurance and Takaful. The measurement and structural model were analyzed by using Structural Equation Modeling (SEM), specifically the Partial Least Squares (PLS). There were two sections in this questionnaire. In the first section of the questionnaire, demographic information was gathered. In the second section of the questionnaire, respondents were asked about their attitude, social norms, perceived behavioural control, knowledge, and purchase intention. This study used convenience sampling technique to identify the respondents as no sampling frame was available. The convenience technique was used due to the practicality of targeting the population within the period of the study (Jernih, Hasmah, \& Azdiana, 2019). Hence, the applicability of the convenience technique seems relevant in this study. A total of 316 questionnaires were found to be valid and complete out of the 580 distributed, thus yielding a response rate of 54.5 percent.

\section{Results and Discussion}

\section{Demographic Profile of Respondents}

The respondents $(n=316)$ were among potential life insurance and Takaful buyers in the Klang Valley. Demographic characteristics such as gender, age, highest education level, and individual monthly income were asked of the respondents. Women made up 62.70 per cent of the sample and males constituted 37.30 per cent of the sample. As for the entire sample, 47.2 per cent of the respondents were between 20 to 30 years old, 23.4 per cent of the respondents were aged between 31 to 40 years, 10.4 per cent of the respondents were aged between 41 to 50 years, 10.1 per cent of the respondents were aged below 20 years old, and 8.9 per cent of the respondents were aged above 50 years old. In regards to the highest education level, 61.7 per cent of the respondents possessed degrees, followed by 15.2 per cent of the respondents who possessed diplomas, 12.7 per cent of the respondents possessed SPM or High School certificates, 7 per cent of the respondents possessed master degrees, 2.2 per cent of the respondents possessed "others", and the remaining 1.3 per cent of the respondents possessed PhDs. Pertaining to individual monthly income, 27.5 per cent of the respondents earned an income between RM3001 to RM5000. This is followed by 24.1 per cent of the respondents earning an income between RM1000 to RM3000, 23.4 per cent of the respondents earned an income of less than RM1000 per month, 17.4 per cent earned an income between RM5001 to RM7000, and the remaining 7.6 per cent of the respondents earned an income of more than RM7000. 
Table 1: Demographic Profile of Respondents

\begin{tabular}{|c|c|c|c|}
\hline Variables & Details & $\begin{array}{l}\text { Frequency } \\
(n=316)\end{array}$ & $\begin{array}{c}\text { Percentage } \\
\text { (\%) }\end{array}$ \\
\hline \multirow[t]{2}{*}{ Gender } & Male & 118 & 37.30 \\
\hline & Female & 198 & 62.70 \\
\hline \multirow[t]{5}{*}{ Age } & Below 20 years old & 32 & 10.10 \\
\hline & $20-30$ years old & 149 & 47.20 \\
\hline & $31-40$ years old & 74 & 23.40 \\
\hline & $41-50$ years old & 33 & 10.40 \\
\hline & Above 50 years old & 28 & 8.90 \\
\hline \multirow{6}{*}{$\begin{array}{l}\text { Highest } \\
\text { Level }\end{array}$} & SPM & 40 & 12.70 \\
\hline & Diploma & 48 & 15.20 \\
\hline & Degree & 195 & 61.70 \\
\hline & Master & 22 & 7.00 \\
\hline & $\mathrm{PhD}$ & 4 & 1.30 \\
\hline & Others & 7 & 2.20 \\
\hline \multirow{5}{*}{$\begin{array}{l}\text { Individual Monthly } \\
\text { Income }\end{array}$} & Less than $\mathrm{RM} 1,000$ & 74 & 23.40 \\
\hline & $\mathrm{RM} 1,000-\mathrm{RM} 3,000$ & 76 & 24.10 \\
\hline & $\mathrm{RM} 3,001-\mathrm{RM} 5,000$ & 87 & 27.50 \\
\hline & $\mathrm{RM} 5,001-\mathrm{RM} 7,000$ & 55 & 17.40 \\
\hline & More than RM7,000 & 24 & 7.60 \\
\hline
\end{tabular}

\section{Assessment of Measurement Model}

The findings of the construct reliability and convergent validity are shown in Table 2. This study measured the internal consistency through Cronbach's alpha and composite reliability. For Cronbach's alpha, a minimum value of 0.7 threshold is needed to establish internal consistency as recommended by Hair, Babin, Money, and Samouel (2005). Based on the analysis, the values for all constructs (i.e. attitude, social norms, perceived behavioural control, mass media, and purchase intention) were higher than 0.7 threshold. Meanwhile, according to Ramayah et al (2018) a value greater than 0.60 threshold is needed to establish composite reliability in the research. All the constructs in this study show values of more than 0.60 threshold for composite reliability. To examine average variance extracted (AVE), Fornell and Larcker (1981) suggested that a value of 0.5 threshold is required to establish average variance extracted. The values for all constructs are above 0.5 threshold, thus, indicating that average variance extracted is established in this study. Hair et al (2017) stated that the acceptable values for indicator loading must be equal to and greater than 0.708 threshold. This is important to indicate that a latent variable is able to explain at least 50 percent of the indicator's variance. Based on the analysis, one item from the social norm construct (i.e item of norms 1 ) was deleted due to poor loadings that was less than 0.708 threshold as suggested by Hair et al. (2017). Overall, the results indicate high internal consistency and sufficient average variance extracted to approve convergent validity in this study. 
Table 2: Assessment of Convergent Validity

\begin{tabular}{|c|c|c|c|c|c|c|}
\hline Constructs & Items & $\begin{array}{l}\text { Indicato } \\
r \\
\text { Loading } \\
s\end{array}$ & $\begin{array}{l}\text { Cronbac } \\
\text { h } \\
\text { Alpha }\end{array}$ & $\begin{array}{l}\text { Composit } \\
\text { e } \\
\text { Reliability } \\
\text { (CR) }\end{array}$ & $\begin{array}{l}\text { Average } \\
\text { Variance } \\
\text { Extracte } \\
\text { d (AVE) }\end{array}$ & $\begin{array}{l}\text { Convergen } \\
t \quad \text { Validity } \\
(\text { AVE }>0.5)\end{array}$ \\
\hline \multirow[t]{3}{*}{ Attitude } & Attitude1 & 0.930 & \multirow[t]{3}{*}{0.919} & \multirow[t]{3}{*}{0.949} & \multirow[t]{3}{*}{0.861} & \multirow[t]{3}{*}{ YES } \\
\hline & Attitude2 & 0.943 & & & & \\
\hline & Attitude3 & 0.911 & & & & \\
\hline \multirow{3}{*}{$\begin{array}{l}\text { Social } \\
\text { Norms }\end{array}$} & Norms2 & 0.783 & \multirow[t]{3}{*}{0.820} & \multirow[t]{3}{*}{0.893} & \multirow[t]{3}{*}{0.736} & \multirow[t]{3}{*}{ YES } \\
\hline & Norms3 & 0.908 & & & & \\
\hline & Norms4 & 0.878 & & & & \\
\hline \multirow{3}{*}{$\begin{array}{l}\text { Perceived } \\
\text { Behaviour } \\
\text { al Control }\end{array}$} & $\begin{array}{l}\text { Perceived } \\
1\end{array}$ & 0.834 & \multirow[t]{3}{*}{0.841} & \multirow[t]{3}{*}{0.904} & \multirow[t]{3}{*}{0.759} & \multirow[t]{3}{*}{ YES } \\
\hline & $\begin{array}{l}\text { Perceived } \\
2\end{array}$ & 0.872 & & & & \\
\hline & $\begin{array}{l}\text { Perceived } \\
3\end{array}$ & 0.906 & & & & \\
\hline \multirow[t]{3}{*}{ Knowledge } & Know1 & 0.826 & \multirow[t]{3}{*}{0.778} & \multirow[t]{3}{*}{0.871} & \multirow[t]{3}{*}{0.692} & \multirow[t]{3}{*}{ YES } \\
\hline & Know2 & 0.845 & & & & \\
\hline & Know3 & 0.824 & & & & \\
\hline \multirow[t]{4}{*}{$\begin{array}{l}\text { Purchase } \\
\text { Intention }\end{array}$} & $\begin{array}{l}\text { Intention } \\
1\end{array}$ & 0.904 & \multirow[t]{4}{*}{0.932} & \multirow[t]{4}{*}{0.951} & \multirow[t]{4}{*}{0.831} & \multirow[t]{4}{*}{ YES } \\
\hline & $\begin{array}{l}\text { Intention } \\
2\end{array}$ & 0.927 & & & & \\
\hline & $\begin{array}{l}\text { Intention } \\
3\end{array}$ & 0.892 & & & & \\
\hline & $\begin{array}{l}\text { Intention } \\
4\end{array}$ & 0.921 & & & & \\
\hline
\end{tabular}

To examine discriminant validity, the researchers used cross-loadings, fornell-larcker, and heterotrait-monotrait ratio of correlations (HTMT) as recommended by Hair et al (2017). The first criterion to examine discriminant validity in this study was by assessing crossloadings. Table 3 demonstrated that the analysis showed outer loading of the construct that is greater than any cross-loadings on other construct as recommended by Ramayah et al. (2018). Clearly, this indicates that the first criterion of discriminant validity has been established in this study. 
Table 3: Cross-Loadings

\begin{tabular}{|l|l|l|l|l|l|}
\hline & & & & & \\
Items & Attitude & Knowledge & $\begin{array}{l}\text { Perceived } \\
\text { Behavioural } \\
\text { Control }\end{array}$ & $\begin{array}{l}\text { Purchase } \\
\text { Intention }\end{array}$ & $\begin{array}{l}\text { Social } \\
\text { Norms }\end{array}$ \\
\hline Attitude1 & $\mathbf{0 . 9 3 0}$ & 0.397 & 0.689 & 0.698 & 0.471 \\
\hline Attitude2 & $\mathbf{0 . 9 4 3}$ & 0.437 & 0.711 & 0.690 & 0.484 \\
\hline Attitude3 & $\mathbf{0 . 9 1 1}$ & 0.368 & 0.694 & 0.727 & 0.501 \\
\hline Norms2 & 0.410 & 0.181 & 0.435 & 0.419 & $\mathbf{0 . 7 8 3}$ \\
\hline Norms3 & 0.501 & 0.280 & 0.488 & 0.558 & $\mathbf{0 . 9 0 8}$ \\
\hline Norms4 & 0.431 & 0.247 & 0.377 & 0.492 & $\mathbf{0 . 8 7 8}$ \\
\hline Know1 & 0.320 & $\mathbf{0 . 8 2 6}$ & 0.358 & 0.328 & 0.252 \\
\hline Know2 & 0.335 & $\mathbf{0 . 8 4 5}$ & 0.339 & 0.311 & 0.226 \\
\hline Know3 & 0.411 & $\mathbf{0 . 8 2 4}$ & 0.484 & 0.371 & 0.219 \\
\hline Intention1 & 0.724 & 0.369 & 0.699 & $\mathbf{0 . 9 0 4}$ & 0.534 \\
\hline Intention2 & 0.72 & 0.361 & 0.651 & $\mathbf{0 . 9 2 7}$ & 0.531 \\
\hline Intention3 & 0.601 & 0.373 & 0.615 & $\mathbf{0 . 8 9 2}$ & 0.556 \\
\hline Intention4 & 0.718 & 0.384 & 0.662 & $\mathbf{0 . 9 2 2}$ & 0.481 \\
\hline Perceived1 & 0.649 & 0.350 & $\mathbf{0 . 8 3 4}$ & 0.649 & 0.514 \\
\hline Perceived2 & 0.624 & 0.448 & $\mathbf{0 . 8 7 2}$ & 0.569 & 0.351 \\
\hline Perceived3 & 0.687 & 0.458 & $\mathbf{0 . 9 0 6}$ & 0.659 & 0.443 \\
\hline
\end{tabular}

The second criterion to assess discriminant validity is by examining the Fornell-Larcker criterion. According to Ramayah et al. (2018), the AVE of a latent variable should be higher than the squared correlation between the latent variable. By looking at Table 4, the values of AVE are higher than the squared correlation between the latent variable. Hence, the second criterion for discriminant validity in this study has been established.

Table 4: Fornell-Larcker Criterion

\begin{tabular}{|l|l|l|l|l|l|}
\hline & & & & & \\
Constructs & Attitude & Knowledge & $\begin{array}{l}\text { Pehavioural } \\
\text { Control }\end{array}$ & $\begin{array}{l}\text { Purchase } \\
\text { Intention }\end{array}$ & $\begin{array}{l}\text { Social } \\
\text { Norms }\end{array}$ \\
\hline Attitude & $\mathbf{0 . 9 2 8}$ & & & & \\
\hline Knowledge & 0.431 & $\mathbf{0 . 8 3 2}$ & & & \\
\hline $\begin{array}{l}\text { Perceived } \\
\text { Behavioural } \\
\text { Control }\end{array}$ & 0.752 & 0.48 & $\mathbf{0 . 8 7 1}$ & & \\
\hline $\begin{array}{l}\text { Purchase } \\
\text { Intention }\end{array}$ & 0.76 & 0.407 & 0.721 & $\mathbf{0 . 9 1 1}$ & \\
\hline $\begin{array}{l}\text { Social } \\
\text { Norms }\end{array}$ & 0.523 & 0.279 & 0.505 & 0.576 & $\mathbf{0 . 8 5 8}$ \\
\hline
\end{tabular}


The third criterion to examine discriminant validity is Heterotrait-Monotrait Ratio of Correlations (HTMT). HTMT values that exceed 0.9 threshold should be avoided as it could be problematic (Gold, Malhotra, \& Segars, 2001). Based on the analysis in Table 5, the values for HTMT is below 0.9 threshold. Thus, this indicates that the third criterion for discriminant validity has been established in this study. As all criterion has been established for discriminant validity, it can be concluded that multi-collinearity issue between items loaded on different constructs in the outer model did not arise. Hence, the researchers proceeded to the next steps of data analysis, that is the assessment of the structural model to test the hypotheses for this study.

Table 5: Heterotrait-Monotrait Ratio of Correlations (HTMT) Criterion

\begin{tabular}{|l|l|l|l|l|l|}
\hline & & & & & \\
Constructs & Attitude & Knowledge & $\begin{array}{l}\text { Perceived } \\
\text { Behavioural } \\
\text { Control }\end{array}$ & $\begin{array}{l}\text { Purchase } \\
\text { Intention }\end{array}$ & $\begin{array}{l}\text { Social } \\
\text { Norms }\end{array}$ \\
\hline Attitude & & & & & \\
\hline Knowledge & 0.506 & & & & \\
\hline $\begin{array}{l}\text { Perceived } \\
\text { Behavioural } \\
\text { Control }\end{array}$ & 0.853 & 0.587 & & & \\
\hline $\begin{array}{l}\text { Purchase } \\
\text { Intention }\end{array}$ & 0.818 & 0.476 & 0.810 & & \\
\hline $\begin{array}{l}\text { Social } \\
\text { Norms }\end{array}$ & 0.600 & 0.345 & 0.603 & 0.654 & \\
\hline
\end{tabular}




\section{Structural Model}

This study used a 5000-bootstrap samples to get stable confidence intervals as suggested by Hair et al's (2017). Table 6 presents the results of the structural model analysis, that included $t$-values for each relationship, $p$-value for each relationship, significant standardized path coefficients, as well as $\left(R^{2}\right)$ for each constructs. The predictive power of the model was determined using $R$-square value $\left(R^{2}\right)$. Meanwhile, the strength of the hypothesized relationship was determined by using the path coefficient. The $R^{2}$ was 0.658 , indicating that 65.8 per cent of the variance in purchase intention can be explained by the four variables, which are attitude, social norms, perceived behavioural control, and knowledge.

The researcher examined the effect size $\left(f^{2}\right)$ in this study as suggested by Cohen (1998). By looking at the analysis, one relationship was found to have medium effect size $\left(f^{2}\right)$; (attitude->purchase intention). Three relationships were found to have small effect size $\left(f^{2}\right)$. These relationship are; (social norms->purchase intention); (perceived behavioural control$>$ purchase intention) and (knowledge->purchase intention). Next, the researchers examined predictive relevance of the model $\left(Q^{2}\right)$. Chin (2010) explained that the model achieved predictive relevance if the value is greater than zero. The predictive relevance of the model $\left(Q^{2}\right)$ in this study was 0.537 . Hence, predictive relevance was achieved in this study.

Four hypotheses were tested in this study to investigate the influence of the independent variables (i.e. attitude, social norms, perceived behavioural control, knowledge towards the dependent variable (i.e. purchase intention). Following the analysis in Table 7, the results indicate that out of four hypotheses, three of them were statistically significant while one hypothesis was not statistically significant. The significant hypotheses in this study were; attitude $(\beta=0.430, p<0.01, t=6.859)$, social norms $(\beta=0.199, p<0.01, t=4.817)$, and perceived behavioural control $(\beta=0.282, p<0.01, t=4.664)$. However, knowledge $(\beta=0.031$, $p<0.01$ ) was not significant in this study.

Table 6: The Results of Structural Model Analysis

\begin{tabular}{|c|c|c|c|c|c|c|c|c|}
\hline Hypothesis & $\begin{array}{l}\text { Standar } \\
\text { d } \\
\text { Beta }\end{array}$ & $\begin{array}{l}\text { Standar } \\
\mathrm{d} \\
\text { Error }\end{array}$ & $\begin{array}{l}t- \\
\text { valu } \\
\mathrm{e}\end{array}$ & $\begin{array}{l}p- \\
\text { value }\end{array}$ & $f^{2}$ & $Q^{2}$ & $\mathrm{R}^{2}$ & Decision \\
\hline $\begin{array}{l}\text { H1: Attitude - } \\
>\quad \text { Purchase } \\
\text { Intention }\end{array}$ & 0.430 & 0.061 & $\begin{array}{l}6.85 \\
9 * *\end{array}$ & 0.000 & 0.217 & 0.537 & 0.658 & $\begin{array}{l}\text { Supporte } \\
\text { d }\end{array}$ \\
\hline $\begin{array}{l}\text { H2: Social } \\
\text { Norms } \quad \text {-> } \\
\text { Purchase } \\
\text { Intention }\end{array}$ & 0.199 & 0.041 & $\begin{array}{l}4.81 \\
7^{* *}\end{array}$ & 0.000 & 0.081 & & & $\begin{array}{l}\text { Supporte } \\
\text { d }\end{array}$ \\
\hline $\begin{array}{l}\text { H3: Perceived } \\
\text { Behavioural } \\
\text { Control -> } \\
\text { Purchase } \\
\text { Intention }\end{array}$ & 0.282 & 0.059 & $\begin{array}{l}4.66 \\
4^{* *}\end{array}$ & 0.000 & 0.091 & & & $\begin{array}{l}\text { Supporte } \\
\text { d }\end{array}$ \\
\hline $\begin{array}{l}\mathrm{H} 4: \\
\text { Knowledge -> } \\
\text { Purchase } \\
\text { Intention }\end{array}$ & 0.031 & 0.041 & $\begin{array}{l}0.68 \\
9\end{array}$ & 0.491 & 0.002 & & & $\begin{array}{l}\text { Not } \\
\text { Supporte } \\
\text { d }\end{array}$ \\
\hline
\end{tabular}

Notes: ${ }^{* *} p<0.01$ 


\section{Discussion}

This study revealed the initial investigation of Muslims intention to purchase life insurance and Takaful. The proposed model showed the predictive power of the constructs in predicting Muslims intention to purchase life insurance and Takaful. The TPB model explained 65.8 per cent of the variance in purchase intention of life insurance and Takaful based on the determinants of attitude, perceived behavioural control, social norm and knowledge. This indicated that 65.8 per cent of purchase intention are explained by the independent variables.

The results showed the robustness of TPB in predicting Muslims intention to purchase life insurance and Takaful. A number of studies have shown the relevancy of TPB in predicting purchase intention (Husin \& Rahman, 2016) but knowledge has not been incorporated as an extended determinant. Out of four proposed hypotheses, three hypotheses were supported that were attitude, social norms, and perceived behavioural control towards the purchase intention of life insurance and Takaful. The hypothesis on knowledge on purchase intention however was not supported. Knowledge is basically a feeling or experiences obtained by people or groups that are gained through the process of learning and experience (Rahman, Asrarhaghighi, \& Rahman, 2015). Even though knowledge is not significant as a predictor of purchase intention, it is positively and significantly correlated with attitude, social norms, and perceived behavioural control. Although there are studies that have documented the strong effect of knowledge and intention in the contextual settings of life insurance and Takaful (Husin \& Rahman, 2013; Husin \& Rahman, 2016), this has not been found to be significant in this research. It is somewhat unexpected that knowledge would not be a substantial criterion of purchase intention of life insurance and Takaful, this may be attributed to purchasers' resistance in intentionally learning or accumulating information about the unsought products like life insurance and Takaful.

It is commonly accepted that people who have positive attitude about life insurance and Takaful are attracted to purchase it. The significant influence of attitude on intention is in line with previous studies (Kasuma et al., 2020; Jalilian et al., 2020; Hasan \& Suciarto, 2020; Rahadjeng \& Fiandari, 2020; Yajid et al., 2020). This study also found social norms as a significant predictor in purchasing life insurance and Takaful. This result suggested that encouragement from the surrounding elements (i.e social norms) attracted people to purchase life insurance and Takaful. This result is in line with past research (Arpaci, 2020; Keat, Zakaria, \& Mohdali, 2020; Anastasia \& Santoso, 2020; Gultom et al., 2020; Usman \& Novianawati, 2020; Khairi et al., 2020). This study also found that perceived behavioural control influence the purchase intention of life insurance and Takaful. This result suggested that there are possibilities that people will purchase life insurance and Takaful if they are equipped with the right resources and have access to the products. In line with this, numerous studies have documented similar results (Jalali et al., 2020; Utami, 2017; Nasir et al., 2020; Nursalwani \& Zulariff, 2017; Nikita, 2015).

\section{Conclusion}

Life insurance and Takaful are important mechanisms used to minimize risks and provide protection against any unanticipated perils. The increasing number of participation in life insurance and Takaful have significant impact on the growth of life insurance and the Takaful industry. Hence, the determination of factors that motivate people to purchase life 
insurance and Takaful are needed to further understand their behavior towards such purchase. The understanding derived from the Theory of Planned Behaviour (TPB) may well pave the way for life insurance and Takaful operators to develop possible strategies to attract potential Muslim buyers. Life insurance and Takaful Operators are in need of relevant inputs to lay down possible strategies in the effort to sustain the products in the marketplace. From a theoretical perspective, there may be more determinants that could be conceptualized in line with the contextual demands to extend further the application of TPB.

From a theoretical standpoint, this study investigates the relevance of the Theory of Planned Behaviour (TPB) in the purchase intention of Muslim consumers in Malaysia towards life insurance and Takaful. The results showed that the TPB model is able to explain 65.8 per cent of the variance in purchase intention of life insurance and Takaful and therefore provides valuable information on the contextual applications of the theory. From a practical perspective, this study contributes valuable inputs to those in the industry for the development and implementation of strategic marketing. As a key contributor the economy, the performance of the insurance industry will indeed be crucial in ensuring the economic growth of the nation.

\section{References}

Agarwal, A. (2017). Knowing 'knowledge' and 'to know': An overview of concepts, International Journal of Research, 5(11), 86-94.

Ajzen, I. (1991). The theory of planned behavior. Organizational Behavior and Human Decision Processes, 50(2), 179-211.

Ajzen, I. (2020). The theory of planned behavior: Frequently asked questions. Human Behavior and Emerging Technologies, 2(4), 314-324.

Ajzen, I., \& Fishbein, M. (1980). Understanding attitudes and predicting social behavior. Englewood Cliffs: Prentice-Hall.

Ajzen, I., \& Madden, T.J. (1986). Prediction of goal-directed behavior: Attitudes, intentions, and perceived behavioral control. Journal of Experimental Social Psychology, 22(5), 453474.

Alam, S. S. \& Sayuti, N. (2011). Applying the Theory of Planned Behavior (TPB) in halal food purchasing. International Journal of Commerce and Management, 21(1), 8-20

Anastasia, N., \& Santoso, S. (2020). Effects of subjective norms, perceived behavioral control, perceived risk, and perceived usefulness towards intention to use credit cards in Surabaya, Indonesia. SHS Web of Conferences 76, 1-11.

Arpaci, I. (2020). The influence of social interactions and subjective norms on social media postings. Journal of Information \& Knowledge Management, 19(3), 1-10.

Chin, W. W. (2010). "Bootstrap Cross-Validation Indices for PLS Path Model Assessment", in Handbook of Partial Least Squares, Vinzi, V.E., Chin, W.W., Henseler, J. \& Wold, H. (Eds), Heidelberg: Springer, 83-97

Cohen, J. (1988). Statistical power analysis for the behavioral sciences. Lawrence Erlbaum, Mahwah, New Jersey.

Fabiola, K. \& Mayangsari, L. (2020). The Influence of Green Skepticism, Environmental Knowledgeand Environmental Concern on Generation Z's Green Purchase Intentions in Indonesia. Malaysian Journal of Social Sciences and Humanities (MJSSH), 5(8), 96 - 105.

Fornell, C., \& Larcker, D. (1981). Evaluating structural equation models with unobservable variables and measurement error. Journal of Marketing Research, 18(3), 39-50.

Gold, A. H., Malhotra, A., \& Segars, A. H. (2001). Knowledge management: An organizational 
capabilities perspective. Journal of Management, 18(1), 185-214.

$\mathrm{Gu}, \mathrm{S} ., \quad \& \mathrm{Wu}, \mathrm{Y}$. (2019). Using the theory of planned behaviour to explain customers' online purchase intention. World Scientific Research Journal, 5(9), 226-249.

Gultom, S., Dalle, J., Restu, Baharuddin, Hairudinoar, \& Gultom, S. (2020). The influence of attitude and subjective norm on citizen's intention to use e-government services. Journal of Security and Sustainability Issues, 9, 173-187.

Hair, F.J., Babin, B., Money, H.A., Samouel, P., (2005). Essentials of Business research Methods. New York: John Wiley \& Sons.

Hair, J.F.J., Hult, G.T.M., Ringle, C.M., \& Sarstedt, M. (2017), A Primer on Partial Least Squares Structural Equation Modeling (PLS-SEM) , 2nd ed., Sage, Thousand Oaks, CA.

Hasan, H. N., \& Suciarto, S. (2020). The influence of attitude, subjective norm and perceived behavioral control towards organic food purchase intention. Journal Of Management and Business Environment, 1(2), 132-153.

Husin, M. M., \& Rahman, A. A. (2013). What drives consumers to participate into family takaful schemes? A literature review. Journal of Islamic Marketing, 4(3), 264-280.

Husin, M. M., \& Rahman, A. A. (2016). Do Muslims intend to participate in Islamic insurance?: Analysis from theory of planned behaviour. Journal of Islamic Accounting and Business Research, 7(1), 42-58.

Jalali M.S., Bruckes M., Westmattelmann D., \& Schewe G. (2020) Why employees (still) click on phishing links: investigation in hospitals. Journal Medical Internet Research, 22(1), e16775.

Jalilian, F., Alavijeh, M. M., Ahmadpanah, M., Mostafaei, S., Kargar, M., Pirouzeh, R., Bahmani, D. S., \& Brand, S. (2020). Extension of theory of planned behavior (TPB) to predict patterns of Marijuana use among young Iranian adults. International Journal of Environmental Research and Public Health, 17, 1-15.

Jernih, A. R., Hasmah, H., Azdiana, S. T. D. (2019). Red blood cell transfusion and associated outcomes in severe isolated traumatic brain injury at Hospital Universiti Sains Malaysia. International Journal of Public Health and Clinical Sciences, 6(6), 148-161.

Kasuma, J., Razak, F. L. A., Omar, N., Naim, A. S. A., Naimullah, B. S. S., \& Darma, D. C. (2020). Attitude, perceived usefulness and perceived ease of use towards intention to use MCommerce: A case of grocery shoppers in Kuching, Sarawak. Journal of Entrepreneurship and Business, 8(1), 71-84.

Keat, P. T. B., Zakaria, W. N. W., \& Mohdali, R. (2020). Factors Influencing Purchase Intention of Life Insurance among Engineering Students. Open International Journal of Informatics(OIJI), 8(1), 1-9.

Khairi, K. F., Laili, N. H., \& Kamarubahrin, A. F. (2020). Malaysian consumer intention toward Takaful scheme for mental health disorders: A preliminary findings using Multiple Regression Analysis. Journal of Islamic Finance, 9(1), 35-45.

Khairunnisa, B. V., \& Hendratmi, A. (2019). The Influence of Product Knowledge and Attitude Towards Intention in Mudharabah Funding Products in Sharia Banks in Mataram" in The 2nd International Conference on Islamic Economics, Business, and Philanthropy (ICIEBP) Theme: "Sustainability and Socio Economic Growth", KnE Social Sciences, 63-677.

Nasir, N. F., Roslin, R. M., \& Chui, T. B. (2020). An extended analysis of Muslims' behavioral intention in purchasing unsought products. International Research Journal of Modernization in Engineering Technology and Science, 2(11), 164-178.

Nikita. (2015). The impact of attitude, subjective norm, perceived behavioral control, trust, 
perceived benefit and perceived risk toward KlikBCA usage intention in Surabaya. iBuss Management, 3(2), 295-303.

Nursalwani, M., \& Zulariff, A. L. (2017). The effect of attitude, subjective norm and perceived behaviour control towards intention of Muslim youth at public universities in Kelantan to consume Halal labelled chocolate bar product. Canadian Social Science, 13(2), 43-48.

Putra, L. S., \& Nurdin, R. (2018). Penerapan theory of planned behavior dalam pembelian makanan halal pada masyarakat di Kota Banda Aceh. Jurnal IImiah Mahasiswa Ekonomi Manajemen, 3(2), 13-21.

Usman, O., \& Novianawati, M. R. F. (2020). Effect of attitude, subjective norm, self-efficacy, against entrepreneurship intentions. 1-16.

Utami, C. W. (2017). Attitude, subjective norms, perceived behavior, entrepreneurship education and self-efficacy toward entrepreneurial intention university student in Indonesia. European Research Studies Journal, XX(2A), 475-495.

Rahadjeng, E. R., Fiandari, Y. R. (2020). The effect of attitude, subjective norms and control of behavior towards intention in share investment. Manajemen Bisnis, 10(2), 17-25.

Rahman, A. A., Asrarhaghighi, E., \& Rahman, S. A. (2015). Consumers and Halal cosmetic products: knowledge, religiosity, attitude, and intention. Journal of Islamic Marketing, 6(1), 148-163.

Ramayah, T., Cheah, J., Chuah, F., Ting, H., \& Memon, M. A. (2018). Partial least squares structural equation modeling (PLS-SEM) using SmartPLS 3.0. Second Edition, Pearson Sdn Bhd, Malaysia.

Rejda, G. E. (2004). Principles of Risk Management and Insurance. 8th Edition, Pearson Education, New Delhi.

Sulaiman, Y., Kan, W. P. E., \& Salimon, M. G. (2020). Purchase Intention towards Organic Food among Undergraduate Students. WSEAS TRANSACTIONS on ENVIRONMENT and DEVELOPMENT, 16, 734-743.

Yajid, M. S. A., Shukri, S. M., \& Azam, S. M. F. (2020). Role attitudes, subjective norms and perceived behavior control in customers' purchase intention. Systematic Reviews in Pharmacy, 11(1), 1064-1072.

Zhang, L., Chen, L., Wu, Z., Zhang, S., \& Song, H. (2018). Investigating young consumers' purchasing intention of green housing in China. Sustainability, 10, 1-1. 